\title{
皐 \\ Illustrations
}

Moonset at Dunsinane, 13/14 August 1040

Moonset at Dunsinane, 13/14 August 1046

5

Sunset at London, 28 December 1594 (Julian)

Sunset at Ephesus, 28 December 1594 (Julian)

Looking east-northeast at Ephesus, 28 December 1594 (Julian)

30 
Steve Sohmer - 9781526135124 